Victor Yavorskiy, Yaroslaw Kalymon and Olga Rubai

\title{
KINETICS OF FERRUM(II) IONS OXIDATION BY AIR OXYGEN IN WATER IN HORIZONTAL ABSORBER WITH BUCKET-LIKE DISPERSERS
}

\author{
Lviv Polytechnic National University \\ 12, St. Bandera str., 79013 Lviv, Ukraine; ffroluch@ukr.net
}

Received: December 12, 2014 / Revised: February 23, 2015 / Accepted: J uly 15, 2015

(C) Yavorskiy V., Kalymon Ya., Rubai O., 2015

\begin{abstract}
The oxidation rate of ferrum(II) to ferrum(III) by air oxygen in water has been investigated in the horizontal absorber with bucket-like dispersers. The reaction order relative to $\mathrm{Fe}^{2+}$ and ${ }^{-} \mathrm{OH}$ ions has been determined based on established dependencies of ferrum(II) ions concentration on dispersion time at their various initial concentrations and medium $\mathrm{pH}$. It has been shown for the first time that at $\mathrm{pH}=5.5-6.2$ in water during oxidation of ferrum(II) ions an autocatalysis occurs due to the formed ferrum(III) ions.
\end{abstract}

Keywords: water treating, groundwater, ferrum(II), oxidation, horizontal absorber, bucket-like disperser.

\section{Introduction}

Ensuring humanity by quality drinking water is becoming an urgent global issue. A drinking quality of river water, which is the main source of water supply in Ukraine and many other countries, systematically decreases; its purification is difficult and expensive. As a result, the usage of groundwater defended from land pollution and partially cleared by penetration through the filtering species is of great importance [1]. However, during penetration through the red-brown soils with limestone patches, reddish sandstone, etc., water is enriched by the compounds of many chemical elements, in particular, compounds of ferrum(II), the content of which may achieve $30 \mathrm{mg} / \mathrm{dm}^{3}$ and more [2]. The allowable content in tap water is $0.2 \mathrm{mg} / \mathrm{dm}^{3}$ and $1.0 \mathrm{mg} / \mathrm{dm}^{3}$ - for water from the wells and cappings [3]. The usage of such drinking water leads to the accumulation of hemosiderine in the liver, which destroys it and increases the risk of myocardial infarction [4].

Water is purified from $\mathrm{Fe}^{2+}$ ions via their oxidation, formation of sparingly soluble $\mathrm{Fe}(\mathrm{OH})_{3}$ and its further removal from water. The main issue is the selection of oxidant, the cost of which determines the cost of treatment. In this respect the use of air oxygen as an oxidant for ions $\mathrm{Fe}^{2+}$ is of great interest. The main problem is creation and maintaining the sufficient concentration of dissolved oxygen in water, because oxygen is very poorly soluble in water [5]. Moreover, this solubility becomes smaller in the presence of dissolved salts.

Groundwater deferrization by air oxygen is accompanied by diffusive and kinetic phenomena because the process includes homogeneous and heterogeneous reactions. The total rate of the process is limited by the rate of air oxygen dilution in water and occurs in the diffusive area. Thus, at water $\mathrm{pH}$ of 6.7 in the open reservoir after $30 \mathrm{~min}$ of the process the deferrization efficiency is only $38 \%$ [6]. If the process time is the same but air is bubbled through water layer the deferrization efficiency increases to $87 \%$ [7]. Such high efficiency is achieved for $7 \mathrm{~min}$ using vacuum ejectors [8]. The effective mass exchange equipment provides the increased contact area between gas and liquid phases. Moreover, the increased rate of oxygen absorption promotes process transfer from the diffusive area into the kinetic one. However, while using vacuum ejectors and injection nozzles the great amount of energy is consumed. To decrease the energy consumption a mass-transfer apparatus ensuring high intensity of oxygen absorption may be used, for example horizontal absorber with bucket-like dispersers [9]. Its specific energy consumption is less by order compared with that of jet apparatuses. The peculiarity of the mentioned absorber is a creation of droplet high rate in the gas flow leading to the minimum thickness of immovable gas film around the droplet. Therefore, the resistance from the direction of the gas phase sharply decreases. Moreover, there is also a low 
resistance from the direction of the liquid phase due to the great number of grinded droplets escaped from the disperser slits and so called "shock effect" - breaking of liquid droplets against apparatus wall or one against an other [9]. Thus, in the case of using horizontal absorber with bucket-like dispersers the diffusion inhibition is sharply minimized and oxidation rate depends on the rate of the chemical reaction. Eq. (1):

It is known [8] that $\mathrm{Fe}^{2+}$ oxidation is described by

$$
4 \mathrm{Fe}^{2+}+\mathrm{O}_{2}+8 \mathrm{OH}^{-}+2 \mathrm{H}_{2} \mathrm{O}=4 \mathrm{Fe}(\mathrm{OH})_{3}
$$

In accordance with Eq. (1) the reaction rate may be represented as Eq. (2):

$$
-\frac{d C_{F^{2+}}}{d \tau}=k \cdot C_{F^{2+}}^{n} C_{O_{2}}^{m} C_{\mathrm{OH}^{-}}^{z}
$$

where $k$ - rate constant; $n, m, z$ - reaction orders relative to the corresponding components; $C_{\mathrm{Fe}^{2+}}, C_{\mathrm{O}_{2}}, C_{\mathrm{OH}^{-}}$ reagents concentrations, $\mathrm{mol} / \mathrm{m}^{3}$.

The increase in oxygen absorption rate leads to the equality of its concentration in water to the equilibrium one and its constancy. It means that the reaction order relative to oxygen may be assumed as zero $(m=0)$ in the apparatus with bucket-like dispersers. To determine the dependence of the reaction rate on the concentration of $\mathrm{Fe}^{2+}$ ions and hydroxy ions it is necessary to know the reaction order relative to each of them.

There is no definite answer to the question about the reaction order relative to ferrum(II) ions - either of the first or the second order $(n=1-2)$. Concerning the reaction order relative to hydroxy ions - mainly it is close to $2(z=2)$. Therefore the aim of the work was to investigate the reaction rate of ferrum(II) oxidation and determine the reaction order relative to $\mathrm{Fe}^{2+}$ and $\mathrm{OH}^{-}$ions.

\section{Experimental}

The investigations were carried out using the laboratory plant illustrated in Fig. 1.

The air by a compressor (1) was fed to the horizontal absorber (5) through a rotameter (3). The air amount was varied by a cock (2). Using a burette (4) $0.1 \mathrm{~N}$ solution of $\mathrm{NaOH}$ was added. The medium $\mathrm{pH}$ was controlled by $\mathrm{pH}$-meter (7) of 150-M type. At the outlet of absorber the droplets of dispersed water were trapped by a drop catcher (6) and returned back to the absorber. The absorber diameter was $0.5 \mathrm{~m}$, its length was $0.3 \mathrm{~m}$. A roller of $0.2 \mathrm{~m}$ diameter with two bucket-like dispersers was situated inside the absorber. According to [9] the optimum linear rate for dispersers was $10 \mathrm{~m} / \mathrm{s}$. The roller was set in motion by an electric motor (8).
The "model" water was prepared using distilled water. Before the experiments it was boiled to remove oxygen and definite amount of $\mathrm{FeSO}_{4}$ solution was added. Water $\mathrm{pH}$ was established and controlled by introducing $0.1 \mathrm{~N} \mathrm{NaOH}$. The initial concentration of $\mathrm{Fe}^{2+}$ ions was varied within $0.5-1.1 \mathrm{~mol} / \mathrm{m}^{3}$; water $\mathrm{pH}$ was $5.5-6.2$. The experiments were carried out at $296 \mathrm{~K}$ under atmospheric pressure. The concentrations of $\mathrm{Fe}^{2+}$ ions were determined using a spectrometry method in accordance with ISO 6332:2003 and $\mathrm{pH}$ - using $\mathrm{pH}-$ meter $150 \mathrm{M}$ with combined electrode ESKL-08M 1.

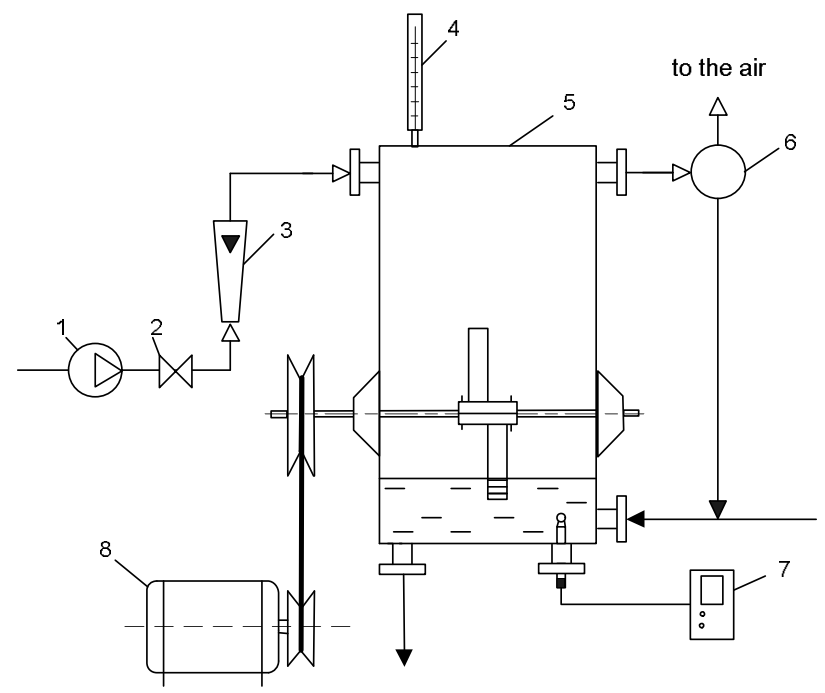

Fig. 1. The scheme of the laboratory plant for $\mathrm{Fe}^{2+}$ and $\mathrm{OH}^{-}$ions oxidation by air oxygen in water: compressor (1); cock (2); rotameter (3); burette (4); horizontal absorber with bucket-like dispersers (5); drop catcher (6); pH-meter (7) and electric motor $(8)$

\section{Results and Discussion}

The change of $\mathrm{Fe}^{2+}$ ions concentration in time was determined using model water with the initial concentrations of $\mathrm{Fe}^{2+}$ ions $0.5,0.7,0.9$ and $1.1 \mathrm{~mol} / \mathrm{m}^{3}$. Water $\mathrm{pH}$ was 5.5, 5.7, 6.0 and 6.2. The dependence of $\mathrm{Fe}^{2+}$ ions concentration on time is represented in Fig. 1.

In the beginning the concentration of $\mathrm{Fe}^{2+}$ ions slightly decreases, then sharply reduces and in the end its change is miserable. At $\mathrm{pH}=5.5$ for the first $2000 \mathrm{~s}$ the concentration reduces from 1.5 to $0.8 \mathrm{~mol} / \mathrm{m}^{3}$, for the next $1500 \mathrm{~s}-$ to $0.2 \mathrm{~mol} / \mathrm{m}^{3}$ and in the end of the process (not shown in Fig. 1) - from 0.2 to $0.3 \cdot 10^{-3} \mathrm{~mol} / \mathrm{m}^{3}$. The general contact time is $10000 \mathrm{~s}$.

To explain the low rate of $\mathrm{Fe}^{2+}$ ions oxidation in the beginning we carried out the additional experiments. The absorber was filled by water without $\mathrm{Fe}^{2+}$ ions and dis- 
solved oxygen and then water was saturated by air oxygen. The experimental results are represented in Fig. 2.

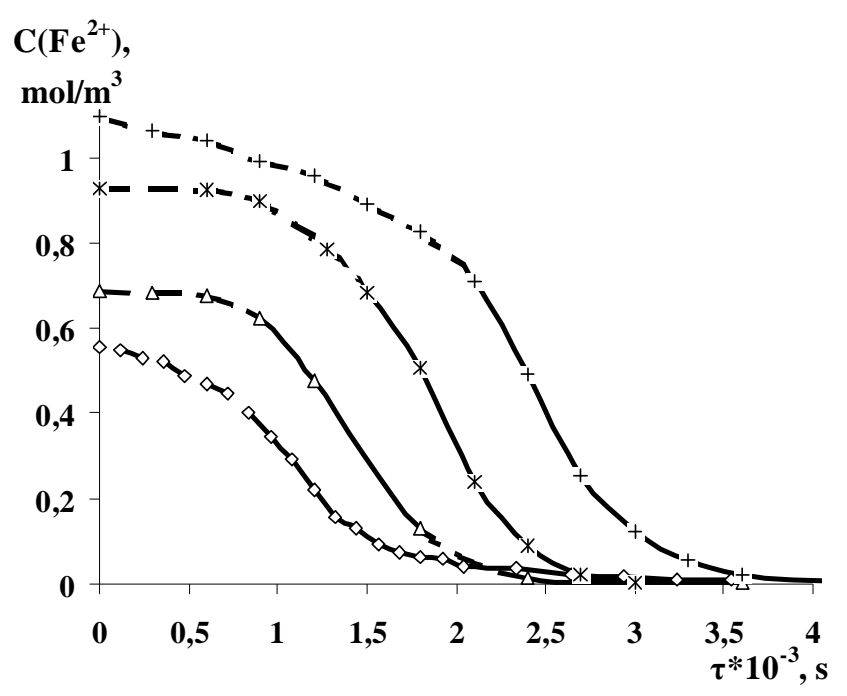

Fig. 1. $\mathrm{Fe}^{2+}$ ions concentration $v$ s. contact time at $\mathrm{pH}=5.5$. The solution initial concentrations $\left(\mathrm{mol} / \mathrm{m}^{3}\right)$ are: $1.1(1) ; 0.8(2)$; 0.7 (3) and 0.5 (4)

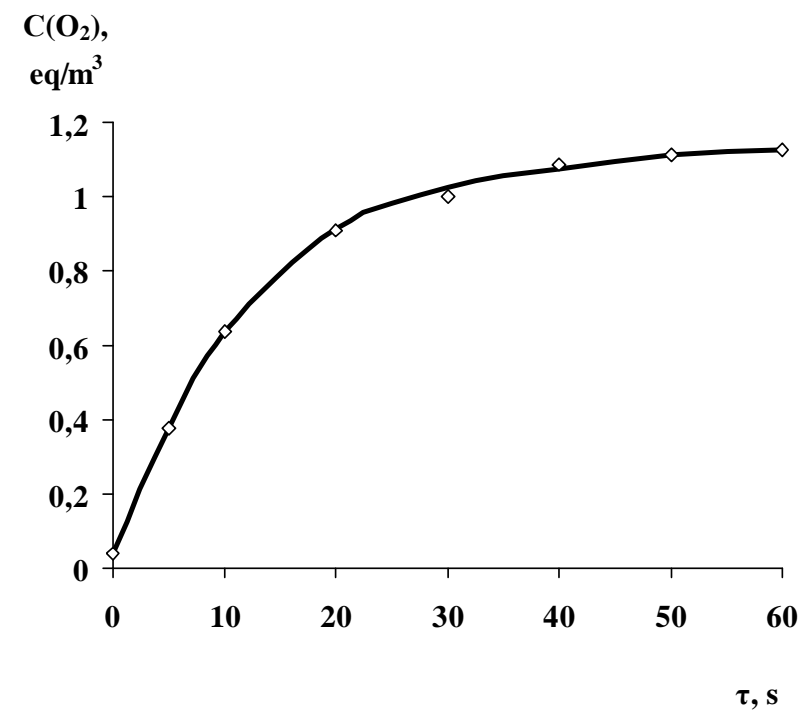

Fig. 2. Dissolved oxygen concentration vs. contact time

After $5 \mathrm{~s}$ the oxygen concentration in water was $0.66 \mathrm{eq} / \mathrm{m}^{3}$, that is equal to $\approx 80 \%$ of saturation. The complete saturation is achieved quickly, after $20 \mathrm{~s}$. It means that the low rate of $\mathrm{Fe}^{2+}$ ions oxidation in the beginning is not limited by the concentration of dissolved oxygen.

A lot of laboratory, factory and commercial tests prove the catalytic properties of ferrum(III) compounds over the surface of filtering material $[5,7]$. Therefore it looks like the intermediate compounds (Eqs. (3) and (4)) are formed in the horizontal absorber with bucket-like dispersers at the start time [8].

$$
\begin{aligned}
\mathrm{Fe}(\mathrm{OH})^{+} & \rightarrow \mathrm{Fe}(\mathrm{OH})^{2+}+e^{-} \\
\mathrm{Fe}(\mathrm{OH})_{2}{ }^{0} & \rightarrow \mathrm{Fe}(\mathrm{OH})_{2}{ }^{+}+e^{-}
\end{aligned}
$$

To study the effect of formed ferrum(III) intermediate compounds on the reaction rate we carried out the special investigations.

We used two kinds of model water with the initial concentration of $\mathrm{Fe}^{2+}$ ions $0.9 \mathrm{~mol} / \mathrm{m}^{3}$ an $\mathrm{pH}=5.7$. The ferrum(III) compounds were added to one kind of water. Other parameters were the same as in the previous investigations.

Fig. 3 shows the dependence of $\mathrm{Fe}^{2+}$ ions concentration on contact time while adding ferrum(III) compounds and without them. In water with ferrum(III) compounds the oxidation rate is high but then it sharply decreases (curve 2). In the second case (without ferrum(III)) the shape of curve 1 is almost the same as the curve from previous investigations with $\mathrm{Fe}^{2+}$ ions concentration of $0.9 \mathrm{~mol} / \mathrm{m}^{3}$ and $\mathrm{pH}=5.7$. It is the confirmation that ferrum(III) compounds have catalytic reactivity not only over the surface of filtrating material [5] but in water volume as well.

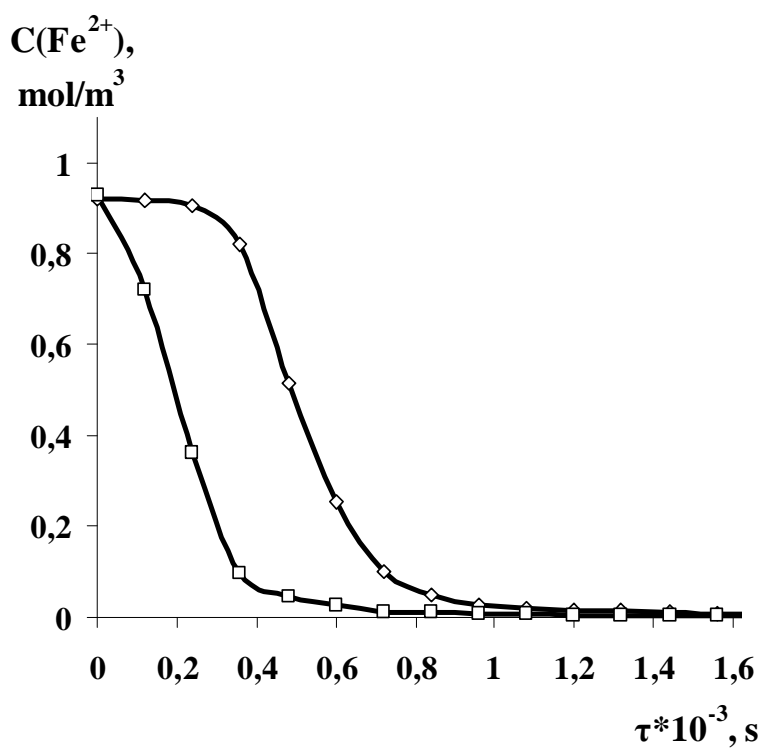

Fig. 3. $\mathrm{Fe}^{2+}$ ions concentration $v s$. contact time at $\mathrm{pH}=5.7$ and initial concentration of $0.9 \mathrm{~mol} / \mathrm{m}^{3}$ : without ferrum(III)

compounds (1) and with ferrum(III) compounds (2)

Taking into account the autocatalytic character of $\mathrm{Fe}^{3+}$ ions action the reaction order of the oxidation reaction relative to $\mathrm{Fe}^{2+}$ and $\mathrm{OH}^{-}$ions were determined using the kinetic curves without initiation period of the intermediate complexes, when $\mathrm{Fe}^{2+}$ ions concentration varies from 0.01 to $0.2 \mathrm{~mol} / \mathrm{m}^{3}$. Within this range the concentrations of dissolved oxygen and ferrum(III) 
compounds are more higher than those of $\mathrm{Fe}^{2+}$ ions. Thus, we assume the concentration of dissolved oxygen as a constant value without the influence on the reaction rate. The catalytic reactivity of ferrum(III) is also constant and does not affect values $n$ and $z$.

The dependence of $\mathrm{Fe}^{2+}$ ions concentration on contact time in the disperser at different values of water $\mathrm{pH}$ is represented in Fig. 4. It is observed from Fig. 4 that at water $\mathrm{pH}=6.2$ the deferrization efficiency achieves $99.7 \%$ after 2 min that confirms the high efficiency of the investigated disperser compared with vacuum ejectors.

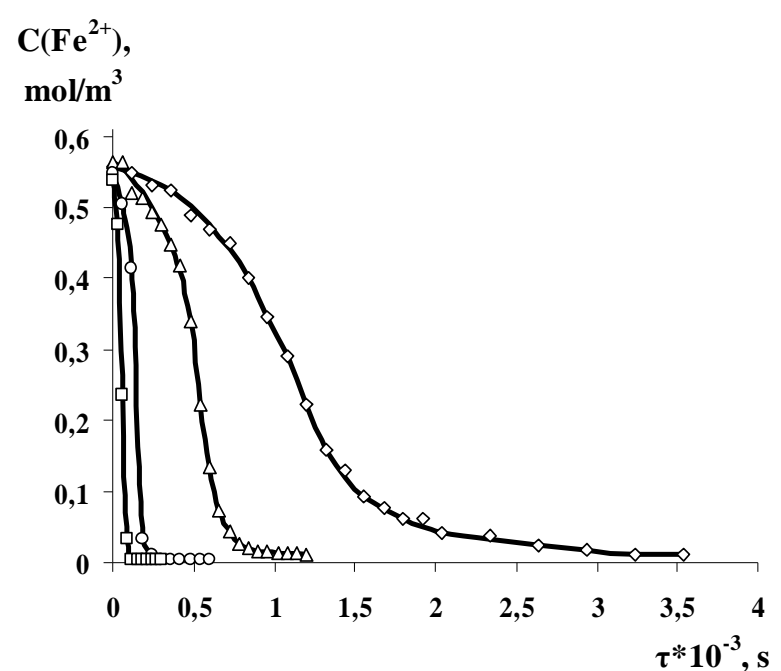

Fig. 4. $\mathrm{Fe}^{2+}$ ions concentration $v s$. contact time at $\mathrm{pH}: 5.5$ $(1) ; 5.7(2) ; 6.0(3)$ and 6.2 (4)

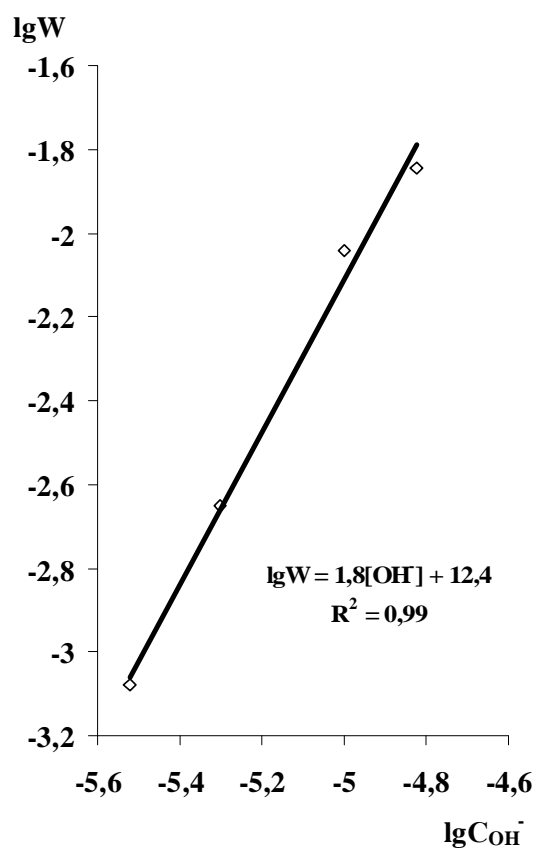

Fig. 5. Dependence of the logarithm of $\mathrm{Fe}^{2+}$ ions oxidation on the logarithm of $\mathrm{OH}^{-}$ions concentration $\left(\mathrm{Fe}^{2+}\right.$ ions concentration is $1.1 \mathrm{~mol} / \mathrm{m}^{3}$ )
The curves (Fig. 5) obtained under the coordinates $\lg W-\lg C$ have the straight character $(W-$ the reaction rate and $C-\mathrm{OH}^{-}$ions concentration). The reaction order relative to $\mathrm{OH}^{-}$ions is 1.9 . The calculated value of the reaction order relative to $\mathrm{Fe}^{2+}$ ions is 0.7 . Taking into account that the oxygen concentration is constant in the apparatus with bucket-like dispersers, the kinetic equation of $\mathrm{Fe}^{2+}$ ions oxidation has the form:

$$
\mathrm{W}=-\frac{d C_{F e^{2+}}}{d \tau}=k^{\prime} \cdot C_{F e^{2+}}^{0.7} C_{O H^{-}}^{1.9}
$$

where $k^{\prime}=k \cdot C_{\mathrm{O}_{2}}$

On the basis of the obtained results we determined $k$, the value of which is hundred times higher than that in other apparatuses [11]. The obtained kinetic equation may be used for the calculations of groundwater purification from ferrum(II) compounds in the apparatus with bucketlike dispersers.

\section{Conclusions}

1. Oxidation of $\mathrm{Fe}^{2+}$ ions by air oxygen in water in the horizontal absorber with bucket-like dispersers at $\mathrm{pH}=5.5-6.2$ occurs in the kinetic area. The reaction order relative to $\mathrm{Fe}^{2+}$ ions is 0.7 and to $\mathrm{OH}^{-}$ions - 1.9. During deferrization there is an excessive concentration of oxygen dissolved in water compared with that of $\mathrm{Fe}^{2+}$ and $\mathrm{OH}^{-}$ions, therefore the reaction order relative to oxygen may be assumed as the zero one.

2. The obtained ferrum(III) compounds have the catalytic reactivity not only over the surface of filtrating material but in the water volume as well.

3 . The use of the horizontal absorber with bucketlike dispersers allows to transfer $\mathrm{Fe}^{2+}$ ions oxidation from diffusion to kinetic area.

\section{References}

[1] Orlov V., Martynov S., Kunytskyi S. and Meddur M.: Resursoekonomichni Mat., Konstrukcii, Budivli i Sporudy, 2012, 23, 646.

[2] Matolych B., Kovalchuk I., Ivanov E. et al.: Pryrodni Resursy Lvivshchyny. PP Lukashchuk, Lviv 2009.

[3] Dergavni Sanitarni Normy ta Pravyla. DSanPiN 2.2.4-171-10.

[4] Krainov S. and Shvets V.: Geokhimiya Podzemnykh Vod Khozyastvenno-Pitievogo Naznacheniya. Nedra, Moskwa 1987.

[5] Nikoladze G.: Obezzhelezivanie Priridnykh i Oborotnykh Vod. Stroiizdat, Moskwa 1978.

[6] Kurbatov A.: PhD thesis, Ros. Khim.Techn. Univ., Moskwa 2014.

[7] Bolotova O.: PhD thesis, Tyumen Gos. Univ., Tyumen 2005.

[8] Zolotova E. and Ass G.: Ochistka Vody ot Zheleza, Ftora, Margantsa i Serovodoroda. Stroiizdat, Moskwa 1975.

[9] Yavorskyi V. and Kalmykov V.: Mat. VIII Miznar. Nauk-Pract. Conf. "Nauka i Osvita 2005", February 7-21, 2005, 74. 
[10] Morgan B. and Lahav O., Chemosphere, 2007, 68, 2080.

[11] Orlov V., Kvartenko O., Martynov S. and Gordienko Y.: Znezaliznennya Pidzemnyh Vod dlya Pytnykh Tsilei. UDUVGP, Rivne 2003.

\section{КІНЕТИКА ОКИСНЕННЯ У ВОДІ ЙОНІВ ФЕРУМУ(II) КИСНЕМ ПОВІТРЯ У ГОРИЗОНТАЛЬНОМУ АБСОРБЕРІ 3 КОВШОПОДІБНИМИ ДИСПЕРГАТОРАМИ}

Анотація. Досліджено швидкість окиснення у воді йонів Феруму(II) до Феруму(III) киснем повітря у горизон- тальному абсорбері з ковщоподібними диспергаторами. На основі встановлених залежностей кониентрацій йонів Феруму(II) у досліджуваній воді від часу диспергування за різних їх початковому вмісту та рН визначено порядок реакиії за йонами $\mathrm{Fe}^{2+}$ та ОН. Вперие встановлено, щуо в об'смі води за рН = 5,5-6,2 при окисненні йонів Феруму(II) має місие явище автокаталізу завдяки утвореним йонам Ферумy (III).

Ключові слова: водопідготовка, очищення підземних вод, окиснення Феруму(II), горизонтальний абсорбер 3 ковиоподібними диспергаторами. 
